\title{
Anna Gumowska, Na peryferiach fanfiction. Najmniejsze formy literackie w fandomie Harry'ego Pottera, Wydawnictwo Uniwersytetu Gdańskiego, Gdańsk 2016, ss. 143
}

Przedstawiana tu publikacja jest dziełem doktorantki Wydziału Filologicznego Uniwersytetu Gdańskiego i stanowi nieco przeredagowaną wersję jej pracy magisterskiej napisanej pod kierunkiem profesor Ewy Rogowskiej-Cybulskiej. Ten udany monograficzny debiut naukowy Anny Gumowskiej w pełni zasługuje na zainteresowanie nie tylko środowiska językoznawczego.

Tytuł książki precyzyjnie zapowiada jej treść - monografia dotyczy małych form literackich powstających w fandomie ${ }^{1}$ Harry'ego Pottera, reprezentujących zatem teksty z zakresu fanfiction ${ }^{2}$, ale stanowiących peryferyjną część twórczości fanów cyklu powieściowego Joanne Rowling. Zwięzły Spis treści (s. 5) rzeczowo przybliża czytelnikowi zawartość kolejnych rozdziałów, jednocześnie dokumentując przejrzystą, dobrze przemyślaną kompozycję całej pracy. W tym miejscu warto podkreślić z uznaniem trafność wyboru tematu dociekań badawczych gdańskiej Autorki. Fanfiction to twórczość literacka mało znana starszej części społeczeństwa, ale ciesząca się dużą popularnością wśród młodych uczestników współczesnej kultury i bardzo dla niej charakterystyczna.

We Wstępie (s. 7-9) znajdujemy autorską zapowiedź nowatorstwa opracowania - jak potwierdza dalsza lektura w pełni zrealizowanego - polegającego na interdyscyplinarnej językoznawczo-genologicznej perspektywie opisu funkcjonowania wybranych małych (tytułowych: najmniejszych) form literackich

1 Fandom - środowisko fanów skupionych wokół jednego tekstu podstawowego; nazwa ta obejmuje zarówno tworzące się w środowisku fanów grupy społeczne, jak i ich szeroko pojęte praktyki, w tym także praktyki literackie (por. s. 141).

2 Fanfiction - zjawisko pisarskiej twórczości fanów bazującej na tekście podstawowym (tu cyklu powieści o Harrym Potterze) i różnorodnych praktyk literackich skupionej wokół niej społeczności (por. tamże). 
w przestrzeni Internetu. Anna Gumowska nie ogranicza się przy tym do analizy jedynie kilku gatunków z fandomu interesującego ją cyklu powieściowego przedstawia je i interpretuje ich rolę na szerokim tle współczesnego życia literackiego w rzeczywistości realnej i wirtualnej, czyniąc to w sposób rzetelny i interesujący. We Wstępie zapowiada też szkicowo zawartość poszczególnych rozdziałów książki oraz wskazuje źródło materiału badawczego, którym jest archiwalne internetowe forum dyskusyjne Twój.net HP Fanfiction.

Rozdział I (,Harry Potter” a kulturowe konteksty zjawiska fanfiction, s. 11-24) przybliża czytelnikowi powstanie zjawiska fanfiction z perspektywy kulturoznawczej. Porównując potteromanię do XVIII-wiecznej gorączki werterowskiej, Autorka podkreśla - znacznie wykraczającą poza zwykłe przejawy uwielbienia - literacką aktywność fanów Harry'ego Pottera. Oryginalnie i twórczo wybiera do opisu tekstów z zakresu fanfiction instrumentarium badawcze wykorzystywane $w$ literackiej teorii apokryficznej. Inteligentnie zauważa bowiem, że „tematyczny związek z kanonem oraz intencja uzupełnienia przedstawionych w nim treści” (s. 14) stanowią wspólną domenę konstrukcyjną apokryfu i fanfiction. Podobieństw między tak, zdawałoby się, dalekimi sobie sferami działalności literackiej Autorka wskazuje zresztą bardzo dużo, co odnotowuję z recenzencką satysfakcją.

W dalszej części rozdziału I uznanie budzi też zgrabne wykorzystanie przez Annę Gumowską modelu relacji zachodzących między poszczególnymi elementami życia literackiego (zaproponowanego przez Krzysztofa Dmitruka w latach 70. XX wieku na podstawie wcześniejszych tez Marii Straszewskiej) do zarysowania cech literatury współczesnej i ukazania fenomenu Harry'ego Pottera na jej tle. Obraz literatury XXI wieku uzupełnia wieloaspektowo przedstawiona przez Autorkę sytuacja pisarskiej twórczości w Internecie.

Celem rozdziału II (Fanfiction potterowe, s. 27-40) jest przybliżenie czytelnikowi zjawiska internetowej literackiej twórczości fanów cyklu Joanne Rowling. Anna Gumowska czyni to, z właściwą jej troską o kontekst kulturowy, na szerszym tle funkcjonowania fanfiction w ogóle. W odniesieniu do fanfiction potterowego wskazuje wykorzystywane w nim gatunki literatury ogólnej oraz specyficzne, charakterystyczne tylko dla niego, dokonując ich wszechstronnego opisu i przeprowadzając różne ich klasyfikacje. Omawia też typy literackich rywalizacji obecnych w potterowym fandomie. Rozdział nie budzi wątpliwości i zastrzeżeń merytorycznych. Autorka świetnie radzi sobie m.in. ze wskazywaniem etymologicznej motywacji pojawiających się tu terminów.

Część analityczno-interpretacyjną książki stanowią rozdziały III-VI (s. 43-128), w których Anna Gumowska szczegółowo omawia cechy charakterystyczne tekstów tworzonych w ramach potterowego fanfiction: limery- 
ków (rozdz. III, s. 43-60), moskalików (rozdz. IV, s. 63-84), lepiei (rozdz. V, s. 87-110) oraz pozostałych małych form literackich (rozdz. VI, s. 113-128). Każdy z gatunków znanych w literaturoznawstwie przedstawiony jest tu najpierw z punktu widzenia genologii ogólnej, a dopiero na tym tle - w odniesieniu do analizowanego fanfiction. Taka powtarzalna struktura opisu pozwala Autorce wskazać w fanowskich realizacjach małych form literackich (głównie poetyckich) ich cechy ogólnogatunkowe, a następnie wyraziście podkreślić znamiona swoiste, potterowe. Autorka czyni to precyzyjnie i dogłębnie, wykazując się zdolnościami interpretacyjnymi tak w zakresie literaturoznawstwa, jak lingwistyki. Nie ogranicza się przy tym do wyszczególnienia i zilustrowania odpowiednimi przykładami kolejno przedstawianych cech, ale każdorazowo trafnie podkreśla ich funkcjonalne uzasadnienie (jak choćby rezygnację z frywolnej tematyki limeryków czy zmianę nacjonalnego bohatera zbiorowego i miejsca kary na realia potterowe w moskalikach).

W przypadku lepiei oraz małych form literackich omawianych w rozdziale VI Autorka w zasadzie samodzielnie tworzy teoretycznoliterackie podwaliny przedstawianych gatunków. Czyni to bardzo sprawnie i przekonująco. Potwierdza tu, ujawnioną już wcześniej, umiejętność dostrzegania wielu różnych aspektów postawionego przed sobą problemu badawczego, wielowymiarowego jego zgłębiania i przystępnego, przejrzystego opisu. Podziw budzi samodzielność sprawnie przeprowadzanych analiz oraz zdolność abstrakcyjnego uogólniania, pozwalająca Autorce budować na ich podstawie przekonującą teorię.

Część zasadniczą książki kończy zgrabne trzystronicowe Zakończenie (s. 131-133), niepowielające - co stanowi niewątpliwą zaletę - treści zawartych we wcześniejszych partiach tekstu i będące widocznym dowodem talentu Autorki do syntezy.

Zamieszczona w książce bogata literatura przedmiotu (s. 135-139), a zwłaszcza liczne i trafne odwołania do niej w tekście świadczą o erudycji Autorki i zdolności do operatywnego wykorzystywania szerokiej wiedzy humanistycznej we własnych naukowych rozważaniach.

Cennym uzupełnieniem tekstu podstawowego jest zamieszczony po bibliografii Słowniczek (s. 141-143), zawierający terminy związane z poruszaną w pracy tematyką, a nieznane powszechnie poza kręgiem zwolenników fanfiction i fanów Harry'ego Pottera (jak choćby: betareading 'redakcja i korekta tekstu fanficion obejmująca poprawki stylistyczne i merytoryczne, a także dbałość o zgodność z kanonem', challenge ‘rodzaj otwartego konkursu, w ramach którego należy napisać tekst fanfiction spełniający podane przez pomysłodawcę warunki', severitus 'gatunek fanfiction z fandomu Harry'ego Pottera 
powstały w odpowiedzi na challenge; podstawowym warunkiem severitusu jest przedstawienie Severusa Snape'a jako ojca Harry'ego Pottera', slash // yaoi 'gatunek fanfiction opisujący relacje homoerotyczne między bohaterami, którzy w tekście podstawowym nie przejawiali tendencji homoseksualnych').

Wszystkie poczynione powyżej uwagi wskazują jednoznacznie, że mamy do czynienia z monografią oryginalną, ważną i potrzebną, mimo że dotyczącą zdawałoby się - tylko niewielkiego wycinka niszowej twórczości literackiej fanów Harry'ego Pottera, zamieszczanej na internetowym forum. Ze względu na kierunek zmian zachodzących we współczesnej kulturze (w tym literackiej) i w zakresie kanałów jej upowszechniania jest to jednak temat istotny, uświadamiający czytelnikowi obecność i rangę nowych obszarów twórczej działalności młodego pokolenia Polaków. A cenna praca Anny Gumowskiej wiedzę na ten mało znany temat odkrywczo nam przybliża. We wzorcowo skomponowanej monografii Autorce udało się przekonująco ukazać korzenie współczesnej twórczości fanowskiej w starszej (apokryfy, limeryki), nowszej (moskaliki) i całkiem nowej (lepieje) tradycji literackiej, a także podkreślić właściwe tej „młodej” sferze życia literackiego nowatorstwo i swoistość. Po publikację tę z korzyścią mogą sięgnąć zarówno lingwiści i literaturoznawcy, jak i kulturoznawcy czy socjolodzy.

Recenzowana książka jest przy tym dziełem interesującym, przystępnym i przyjemnym w lekturze, co zawdzięcza przejrzystemu, jasnemu, a zarazem stricte naukowemu stylowi oraz umiejętności posługiwania się poprawną polszczyzną przez Autorkę. Słowa uznania należą się też grafikowi Wydawnictwa Uniwersytetu Gdańskiego, Filipowi Sendalowi, który urozmaicił tekst monografii biało-czarnymi ilustracjami poprzedzającymi każdy rozdział, z powodzeniem wprowadzającymi czytelnika w atmosferę tajemniczego, baśniowego, potterowego świata. 

